Note

\section{Transformation of Glutamyl Dipeptides by Heating in Aqueous Solution}

\section{Takanori KasaI, Tsuyoshi Nishitoba and Sadao SAKAMURA}

\author{
Department of Agricultural Chemistry, \\ Faculty of Agriculture, \\ Hokkaido University, \\ Sapporo 060, Japan
}

Received April 28, 1983

Several methods have been proposed to distinguish $\alpha$ GP* from $\gamma$-GP. ${ }^{1)}$ Le Quesne and Young have reported that $\alpha$-GP changes to pyro-derv and $\gamma$-GP undergoes an intramolecular substitution resulting in fission of the peptide bond when they are heated in an aqueous solution $\left(100^{\circ} \mathrm{C}, 24 \mathrm{hr}\right){ }^{2)}$ We tried to utilize this simple reaction to distinguish between $\alpha$-GP and $\gamma-\mathrm{GP}$, and found that the formation of DKP-derv as well as pyro-derv from some $\alpha$-GPs and hydrolysis of $\gamma$-GPs occur under the milder condition described below. The transformations of $\alpha$ - and $\gamma$-GPs during autoclaving which is usually utilized for sterilization process are also described.

General methods. Paper chromatography (PC) was carried out in $n$-BuOH-AcOH- $\mathrm{H}_{2} \mathrm{O}$ (4:1:2). High voltage paper electrophoresis (HVE) was performed at pH 3.6 (pyridine- $\mathrm{AcOH}-\mathrm{H}_{2} \mathrm{O}, 1: 20: 200,50 \mathrm{v} / \mathrm{cm}$ ). Pyro, pyro-dervs, DKP-dervs and $N$-glutaryl-AIB were detected with aniline-xylose reagent $(1 \mathrm{~g}$ of xylose and $1 \mathrm{ml}$ of aniline in $3 \mathrm{ml}$ of $\mathrm{H}_{2} \mathrm{O}, 94 \mathrm{ml}$ of $\mathrm{MeOH}$ added).

Preparation of $\alpha$ - and $\gamma$-GPs. Glu and other amino acids used for the synthesis of dipeptides were all $\mathrm{L}$-form except for gly, AIB and $\beta$-ala. See the previous papers for preparation of $\alpha$ - and $\gamma$-GPs ${ }^{3)}$ and $N$-glutaryl AIB ${ }^{4)} \gamma$-LGlu-L-phe and $\gamma$-L-glu-L-tyr were isolated from ladino clover seeds. ${ }^{5)}$

Effect of reaction time. The $\alpha$ - and $\gamma$-GPs of gly, val and leu were each dissolved in $\mathrm{H}_{2} \mathrm{O}(1 \mathrm{mg} / 0.5 \mathrm{ml})$ and heated in a sealed tube at $c a .110^{\circ} \mathrm{C}$ for 5 and $15 \mathrm{hr}$. The PC and HVE patterns of the reaction mixture of each sample after reacting for $5 \mathrm{hr}$ were the same as those after reacting for $15 \mathrm{hr}$ in all cases.

Transformation of $\alpha$ - and $\gamma-G P$ s by heating in an aqueous solution. The $\alpha$ - and $\gamma$-GPs of ala, $\beta$-ala, AIB, asn, gly, leu, trp and val and $\alpha$-glu-asp were each dissolved in $\mathrm{H}_{2} \mathrm{O}$ $(1 \mathrm{mg} / 0.5 \mathrm{ml})$ and heated in sealed tubes $\left(c a .110^{\circ} \mathrm{C}, 5 \mathrm{hr}\right)$. A mixture of $\gamma$-glu-phe and $\gamma$-glu-tyr $(1 \mathrm{mg}$ each $/ 0.5 \mathrm{ml})$ was also heated under the same conditions. Each reaction mixture was examined by PC and HVE (Table I). All of the $\gamma$-GPs were hydrolyzed to pyro and C-terminal amino acid even when this C-terminal amino acid was hydrophobic, such as leu, trp, tyr or phe which had not been examined in the previous report. ${ }^{2)}$ Two weak spots were detected on the HVE of a reaction mixture of $\alpha$-glu-asp besides distinct spots of pyro and asp with aniline-xylose reagent. $\alpha$-Glu-asn also gave the same four spots as those from $\alpha$-glu-asp. The reaction mixture of $\alpha$-gluAIB gave two spots on PC and HVE which did not agree with either pyro or AIB. The reaction mixtures of other $\alpha$-GPs gave one strong spot on PC and HVE with aniline-xylose reagent, which was considered to be pyroderv. Isolation and identification of the reaction product was then conducted, the starting material not being detected in all cases after heating.

Formation of pyro-leu and pyro-val from $\alpha$-glu-leu and $\alpha$ glu-val, respectively. $\alpha$-Glu-leu $(60 \mathrm{mg})$ was dissolved in $\mathrm{H}_{2} \mathrm{O}(5 \mathrm{ml})$ and heated in a sealed tube $\left(c a .110^{\circ} \mathrm{C}, 5 \mathrm{hr}\right) . \mathrm{A}$ product giving a strong reaction to aniline-xylose was isolated by preparative PC as a crystalline evaporation residue ( $35.3 \mathrm{mg}$, some loss during concentration). The product was identified as pyro-leu by FDMS and PMR spectra using the titration shift technique. FDMS $(\mathrm{m} / \mathrm{z})$ : $243\left(\mathrm{M}^{+}+1,100 \%\right), 84$ (pyrrolidone residue, 38.6). See Table 2 for the titration shift on the PMR spectrum. Pyroval $(41.2 \mathrm{mg}$ as a crystalline residue) was isolated and identified by the same procedures as those for pyro-leu starting from $\alpha$-glu-val $(50 \mathrm{mg})$. FDMS $(\mathrm{m} / \mathrm{z}): 229$ $\left(\mathrm{M}^{+}+1,100 \%\right), 83$ (pyrrolidone residue, 46.7). See Table II for the titration shift on the PMR spectrum.

Formation of pyro-asp and cyclo (glu-asp) from $\alpha$-gluasn and $\alpha$-glu-asp. $\alpha$-Glu-asn $(100 \mathrm{mg})$ was dissolved in $\mathrm{H}_{2} \mathrm{O}(10 \mathrm{ml})$ and heated in a sealed tube $\left(c a .110^{\circ} \mathrm{C}, 5 \mathrm{hr}\right)$. Four spots were revealed on the HVE of the reaction mixture by aniline-xylose reagent. Two of these corresponded to pyro and asp, respectively. Two other products were separated from each other by preparative PC and HVE. A product with a higher $R f$ value on $\mathrm{PC}$ and faster mobility on $\operatorname{HVE}(8.5 \mathrm{mg}$ as a crystalline evap-

* Abbreviations: GP, glutamyl peptides; pyro, pyroglutamic acid; pyro-derv, pyroglutamyl derivative; DKP-derv, diketopiperazine derivative, also expressed as cyclo ( $\mathrm{x}-\mathrm{y}$ ), for example cyclo (glu-asp) for the diketopiperazine derivative formed from glutamic acid and aspartic acid; ala, alanine; asn, asparagine; asp, aspartic acid; AIB, $\alpha$-aminoisobutyric acid; $\beta$-ala, $\beta$-alanine; glu, glutamic acid; gly, glycine; leu, leucine; phe, phenylalanine; trp, tryptophant; tyr, tyrosine; val, valine. 
Table I. Main Products Formed from $\alpha$ - and $\gamma$-Glutamyl Dipeptides by Heating in an Aqueous Solution (in a Sealed Tube, ca. $110^{\circ} \mathrm{C}, 5 \mathrm{hr}$ )

\begin{tabular}{|c|c|c|c|}
\hline & \multicolumn{2}{|c|}{$\mathrm{PC}\left(n-\mathrm{BuOH}-\mathrm{AcOH}-\mathrm{H}_{2} \mathrm{O}, 4: 1: 2\right)$} & $\begin{array}{l}\mathrm{HVE}\left(\mathrm{pH} 3.6^{a}\right) \\
\text { Aniline-Xylose }\end{array}$ \\
\hline$\alpha$-L-glu-L-leu & & pyro-leu $\left(4.65^{b}\right)$ & pyro-leu $\left(2.36^{b}\right)$ \\
\hline$\gamma$-L-glu-L-leu & leu & pyro & pyro \\
\hline$\alpha$-L-glu-L-val & & pyro-val (3.52) & pyro-val $(2.64)$ \\
\hline$\gamma$-L-glu-L-val & val & pyro & pyro \\
\hline$\alpha$-L-glu-gly & gly & pyro-gly (2.05), pyro & pyro-gly (3.33), pyro \\
\hline$\gamma$-L-glu-gly & gly & pyro & pyro \\
\hline$\alpha$-L-glu-L-trp & & pyro-trp $(3.20)$ & pyro-trp (1.71) \\
\hline$\gamma$-L-glu-L-trp & $\operatorname{trp}$ & pyro & pyro \\
\hline $\begin{array}{l}\alpha \text {-L-glu-AIB } \\
\gamma \text {-L-glu-AIB }\end{array}$ & AIB & $\begin{array}{l}\text { pyro-AIB (3.66), cyclo(glu-AIB) } \\
(1.96), \text { pyro }\end{array}$ & $\begin{array}{l}\text { pyro-AIB (1.73), cyclo(glu-AIB) }(0.80) \\
\text { pyro }\end{array}$ \\
\hline$\alpha$-L-glu-L-asn & asp & $\begin{array}{l}\text { pyro-asp (1.59), cyclo(glu-asp) } \\
(1.26), \text { pyro }\end{array}$ & $\begin{array}{l}\text { pyro-asp (4.00), cyclo(glu-asp) (2.07), } \\
\text { pyro, asp }^{c}\end{array}$ \\
\hline$\gamma$-L-glu-L-asn & asp & pyro & pyro, asp ${ }^{c}$ \\
\hline $\begin{array}{l}\alpha \text {-L-glu- } \beta \text {-ala } \\
\gamma \text {-L-glu- } \beta \text {-ala }\end{array}$ & $\beta$-ala & $\begin{array}{l}\text { pyro- } \beta \text {-ala }(2.29) \\
\text { pyro }\end{array}$ & $\begin{array}{l}\text { pyro- } \beta \text {-ala }(1.07) \\
\text { pyro }\end{array}$ \\
\hline $\begin{array}{l}\alpha \text {-L-glu-L-ala } \\
\gamma \text {-L-glu-L-ala }\end{array}$ & ala & $\begin{array}{l}\text { pyro-ala }(2.75) \\
\text { pyro }\end{array}$ & $\begin{array}{l}\text { pyro-ala }(2.87) \\
\text { pyro }\end{array}$ \\
\hline$\alpha$-L-glu-L-asp & asp & pyro & pyro, asp ${ }^{c}$ \\
\hline $\left.\begin{array}{l}\gamma \text {-L-glu-L-tyr } \\
\gamma \text {-L-glu-L-phe }\end{array}\right\} \operatorname{mix}$ & tyr, phe & Not developed & Not developed \\
\hline
\end{tabular}

a See the text for the composition of the buffer solution.

$b$ Relative mobility to glu.

c Although asp was detected on HVE, it was not recognized on PC.

Table II. Titration Shifts on PMR Spectra $(90 \mathrm{MHz})$ of Some Important Signals of Pyroglutamyl and Diketopiperazine Derivatives Formed FROM $\alpha$-Glutamyl Dipeptides by Heating

\begin{tabular}{|c|c|c|c|}
\hline & In $\mathrm{DCl}(\mathrm{p} D<1)(\mathrm{a})$ & In NaOD (pD>13) (b) & (a)-(b) \\
\hline \multicolumn{4}{|l|}{ Pyro-leu } \\
\hline $\begin{array}{l}\text { Centre of } \mathrm{CH}_{2} \text { derived from } \gamma-\mathrm{CH}_{2} \\
\text { of glu residue of } \alpha \text {-glu-leu }\end{array}$ & 2.40 & 2.40 & 0 \\
\hline $\begin{array}{l}\text { Centre of } \mathrm{CH} \text { derived from } \alpha-\mathrm{CH} \\
\text { of leu residue of } \alpha \text {-glu-leu }\end{array}$ & 4.34 & 4.16 & 0.18 \\
\hline \multicolumn{4}{|l|}{ Pyro-val } \\
\hline $\begin{array}{l}\text { Centre of } \mathrm{CH}_{2} \text { derived from } \gamma-\mathrm{CH}_{2} \\
\text { of glu residue of } \alpha \text {-glu-val }\end{array}$ & 2.47 & 2.46 & 0.01 \\
\hline $\begin{array}{l}\text { Centre of } \mathrm{CH} \text { derived from } \alpha-\mathrm{CH} \\
\text { of val residue of } \alpha \text {-glu-val }\end{array}$ & 4.26 & 4.05 & 0.21 \\
\hline \multicolumn{4}{|l|}{ Cyclo(glu-asp) } \\
\hline $\begin{array}{l}\text { Centre of } \mathrm{CH}_{2} \text { derived from } \gamma-\mathrm{CH}_{2} \\
\text { of glu residue of } \alpha \text {-glu-asn }\end{array}$ & 2.50 & 2.18 & 0.32 \\
\hline $\begin{array}{l}\text { Centre of } \mathrm{CH}_{2} \text { derived from } \beta-\mathrm{CH}_{2} \\
\text { of asn residue of } \alpha \text {-glu-asn }\end{array}$ & 2.97 & 2.71 & 0.28 \\
\hline
\end{tabular}


oration residue) was identified as pyro-asp by its FDMS spectrum. FDMS $(m / z): 245\left(\mathrm{M}^{+}+1,60.8 \%\right), 227(245$ $-\mathrm{H}_{2} \mathrm{O}, 56.0$ ), 83 (pyrrolidone residue, 100). The other with a lower $R f$ value on PC and slower mobility on HVE (18.0 $\mathrm{mg}$ as an evaporation residue) was identified as cyclo(glu-asp) by FDMS and PMR spectra using the titration shift technique. FDMS $(m / z): 245\left(\mathrm{M}^{+}+1,100 \%\right)$. See Table II for the titration shift on the PMR spectrum. No product having an asn residue was detected. Both the pyro-asp and cyclo(glu-asp) were also found in the reaction mixture of $\alpha$-glu-asp after the same treatment, but the yield of both derivatives was much less than those from $\alpha$-glu-asn, judging from the intensities of their spots on PC and HVE. Most of the $\alpha$-glu-asp was hydrolyzed to pyro and asp. The reason for this difference in yield is unknown. Le Quesne and Young did not describe the formation of pyro-asp and cyclo(giu-asp) from $\alpha$-glu-asp. ${ }^{2)}$ The difference between their result and this report might be due to the different reaction conditions.

Formation of pyro-AIB and cyclo(glu-AIB) from $\alpha$-gluAIB. $\alpha$-Glu-AIB $(100 \mathrm{mg})$ was dissolved in $\mathrm{H}_{2} \mathrm{O}(10 \mathrm{ml})$ and heated in a sealed tube $\left(\mathrm{ca} .110^{\circ} \mathrm{C}, 5 \mathrm{hr}\right)$. The reaction mixture gave two spots on $\mathrm{PC}$ and $\mathrm{HVE}$ as described above. A product with a higher $R f$ value on $\mathrm{PC}$ and longer migration on HVE was isolated as a crystalline evaporation residue $(52.1 \mathrm{mg})$ by preparative $\mathrm{PC}$ and identified as pyro-AIB by FDMS and PMR spectra, which showed no significant titration shift. FDMS $(m / z): 215\left(\mathrm{M}^{+}+1\right.$, $100 \%$ ), 84 (pyrrolidone residue, 35.4). The other product with a lower $R f$ value on $\mathrm{PC}$ and slower migration on HVE isolated as an evaporation residue $(39.9 \mathrm{mg})$ by preparative PC was further purified by preparative HVE and identified as cyclo(glu-AIB) by its FDMS spectrum. FDMS $(\mathrm{m} / \mathrm{s}): 215\left(\mathrm{M}^{+}+1,100 \%\right)$. The titration shift on the PMR spectrum could not be determined because the compound was hydrolyzed to glu and AIB during measurement of the PMR spectrum under basic $(\mathrm{p} D>13)$ and acidic $(\mathrm{p} D<1)$ conditions.

Pyro- $\beta$-ala from $\alpha$-glu- $\beta$-ala. $\alpha$-Glu- $\beta$-ala $(5 \mathrm{mg})$ was dissolved in $\mathrm{H}_{2} \mathrm{O}(1 \mathrm{ml})$ and heated in a sealed tube ( $c a$. $110^{\circ} \mathrm{C}, 5 \mathrm{hr}$ ). Since the reaction mixture gave one spot on PC and HVE with aniline-xylose reagent, the FDMS spectrum of the reaction mixture was determined without further purification and the product was identified as pyro$\beta$-ala. It is considered that the formation of cyclo(glu- $\beta$ - ala) which has a 7-membered ring is much more difficult than that of the usual DKP-dervs with a 6-membered ring. FDMS $(m / z): 201\left(\mathrm{M}^{+}+1,100 \%\right), 84$ (pyrrolidone residue, 35.7).

Heating of $N$-glutaryl AIB. The formation of pyro-derv from $\alpha$-GP and pyro from $\gamma$-GP should be caused by the presence of an $\mathrm{NH}_{2}$ group of the glu residue. To confirm the role of the $\mathrm{NH}_{2}$ group in these reactions, an aqueous solution of $\mathrm{N}$-glutaryl AIB, which has no free $\mathrm{NH}_{2}$ group, $(1 \mathrm{mg} / 0.5 \mathrm{ml})$ was heated in a sealed tube $\left(c a .110^{\circ}, 5 \mathrm{hr}\right)$. Although the formation of a trace amount of AIB was detected with ninhydrin, the intensity of the starting material on PC hardly changed.

Transformation of $\alpha$ - and $\gamma-G P$ during autoclaving. A mixture of the $\alpha$ - and $\gamma$-GPs of asn, ala and val (1 mg each) was dissolved in $\mathrm{H}_{2} \mathrm{O}(0.5 \mathrm{ml})$ and autoclaved $(1.1 \mathrm{~atm}$, $\left.120^{\circ} \mathrm{C}, 15 \mathrm{~min}\right)$ to see whether the decrease of $\alpha$ - and $\gamma$-GPs take place under the conditions usually used for the sterilization process. The decrease of each GP was calculated with an amino acid analyzer. A residual amount $(\%)$ after autoclaving resulted; $\alpha$-glu-asn $(4.4 \%), \alpha$-glu-ala (33.0), $\alpha$-glu-val (30.8), $\gamma$-glu-asn ( 0 , but $\gamma$-glu-asp corresponding to $c a .20 \%$ of $\gamma$-glu-asn was observed), $\gamma$-gluala (50.5) and $\gamma$-glu-val (77.6). This experiment revealed that a considerable part of $\alpha$ - and $\gamma$-GPs are lost by the autoclaving process used for sterilization.

Acknowledgments. We express our gratitude to Professor T. Shiba for supplying $\alpha$-glu-asp and $\mathrm{Mr}$. K. Watanabe for measurement of FDMS spectra.

\section{REFERENCES}

1) T. Kasai and P. O. Larsen, Fortschr. Chem. Org. Naturst., 39, 173 (1980).

2) W. J. Quesne and G. T. Young, J. Chem. Soc., 594 (1952).

3) T. Kasai and S. Sakamura, Agric. Biol. Chem., 37, 685, 2155 (1973); T. Kasai, P. O. Larsen and H. S $\phi$ rensen, Phytochemistry, 17, 1911 (1978).

4) T. Kasai and S. Sakamura, Nippon Nôgeikagaku Kaishi, 48, 521 (1974).

5) T. Kasai, M. Ueda, S. Sakamura and K. Sakata, Nippon Nôgeikagaku Kaishi, 47, 583 (1973). 